\title{
A preliminary study on the lithospheric thermal structure and rheology of the Tibetan plateau*
}

\author{
Yang Wang * \\ Division of Petrology, School of Earth Sciences and Resources, China University of Geosciences, \\ Beijing 100083, China
}

\begin{abstract}
The lithosphere temperature beneath the Tibetan plateau was estimated by local isostasy equilibrium constrained geothermal calculation. Maps of the lateral temperature variation at depths of $40 \mathrm{~km}, 70 \mathrm{~km}$, and Moho are presented for the Tibetan plateau, and the thermal thickness of the lithosphere is also presented. The Tibetan plateau has a warm and thick lithospheres, but the thinner lithospheres are identified in the northern Tibet and the eastern margin of the plateau. The warm and soft lithospheres in the Tibetan plateau may represent a snapshot of the early stage of convective thinning of the convergent lithosphere. The "crème brûlée" layering demonstrates the rheological behavior of the Tibetan plateau.
\end{abstract}

Key words: geotherm; isostasy; rheology; lithosphere; Tibetan plateau

CLC number: P314.2 Document code: A

\section{Introduction}

The Tibetan plateau exhibits significant lateral variations of crustal structure, lithosphere thickness and temperature distributions (e.g. Wang, 2001; Klemperer, 2006; Zhang et al., 2011). Accordingly, the study on the thermal state and strength of the continental lithosphere in the Tibetan plateau provides not only insights on the present-day geodynamics for this geologically intriguing landmass, but also information about the spatial variability of lithospheric rheology in a highly heterogeneous region. Previous studies on the lithosphere thermal state of Tibetan plateau relied on the heat flow observations only (Huang et al., 1996a, b; Wang, 1996). Unfortunately, there lack sufficient observations in the most area of the Tibetan plateau (Wang and Huang, 1990; Wang, 1996; Hu et al., 2000, 2001; Wang, 2001). To avoid the difficulty from the biased geographic distribution and intrinsic errors of some heat flow observations, here we use local isostasy

\footnotetext{
* Received 18 February 2012; accepted in revised form 20 June 2012; published 10 December 2012.

* Corresponding author. e-mail: allen_thalassa@sina.com

(c) The Seismological Society of China, Institute of Geophysics, China Earthquake Administration, and Springer-Verlag Berlin Heidelberg 2012
}

analysis to constrain the lithosphere temperature distributions of the Tibetan plateau. The $1^{\circ} \times 1^{\circ}$ grid based maps of the lateral temperature distributions at $40 \mathrm{~km}$, $70 \mathrm{~km}$, and Moho depths are presented, either maps of the thermal lithosphere thickness and the lithosphere strength. The results provide a more robust approximation to the lithosphere thermal structure and the rheology of the Tibetan plateau.

\section{Geothermal modelling}

\subsection{Geothermal gradient reconstruction}

Detailed descriptions on the methodology to reconstruct the lithospheric thermal structure can be found in Wang and Cheng (2012). An abbreviated outline is provided below.

Under 1-D steady state assumption the temperature distribution in the lithosphere is determined by the following equation:

$$
-\operatorname{div}(-k \operatorname{grad} T)+A=0,
$$

where $k$ is the thermal conductivity $\left(\mathrm{W} \cdot \mathrm{m}^{-1} \cdot \mathrm{K}^{-1}\right), T$ is temperature $\left({ }^{\circ} \mathrm{C}\right)$, and $A$ is radiogenic heat production $\left(\mu \mathrm{W} \cdot \mathrm{m}^{-3}\right)$.

Relative topographic variations, assuming local isostasy and taking into account density variations due 
to thermal expansion in the lithospheric mantle, can be used to constrain the vertical distribution of temperature within the lithosphere (geotherm) (Zeyen and Fernandez, 1994). Assuming local isostatic conditions, the absolute elevation of a given lithospheric column is determined by comparing its buoyancy force with that of a reference column. Taking the reference column at the mid-oceanic ridges, the surface elevation is given by (Lachenbruch and Morgan, 1990)

$$
E=\frac{\rho_{\mathrm{a}}-\rho_{\mathrm{l}}}{\rho_{\mathrm{a}}} L-H_{0} \quad E \geq 0,
$$

where $E$ is elevation above sea level $(\mathrm{m}), \rho_{\mathrm{a}}$ is density of the asthenosphere $\left(\mathrm{kg} \cdot \mathrm{m}^{-3}\right), \rho_{\mathrm{l}}$ is mean density of the lithosphere $\left(\mathrm{kg} \cdot \mathrm{m}^{-3}\right), L$ is thickness of the lithosphere $(\mathrm{m})$, and $H_{0}$ is depth below sea level of an unloaded asthenospheric mantle $(\mathrm{m})$. In this study, $H_{0}$ is taken to be $-2400 \mathrm{~m}$, and the density of lithospheric mantle is assumed to increase upward with decreasing temperature (Lachenbruch and Morgan, 1990). Therefore

$$
\rho_{\mathrm{m}}(z)=\rho_{\mathrm{a}}\left[1+\alpha\left(T_{\mathrm{a}}-T(z)\right)\right]
$$

where $\rho_{\mathrm{m}}(z)$ is density in the lithospheric mantle $\left(\mathrm{kg} \cdot \mathrm{m}^{-3}\right), \alpha$ is thermal expansion coefficient $\left(\mathrm{K}^{-1}\right), T_{\mathrm{a}}$ is temperature at the lithosphere-asthenosphere boundary
(LAB) $\left({ }^{\circ} \mathrm{C}\right)$, and $T(z)$ is temperature in the lithospheric mantle $\left({ }^{\circ} \mathrm{C}\right)$, and $z$ is depth.

The mean elevation of each $1^{\circ} \times 1^{\circ}$ latitudelongitude grid derived from the ETOP5 model is used as the fitting target in this study. The trial-and-error method is applied to search the surface heat flow value and obtain a minimum misfit of the elevation in each $1^{\circ} \times 1^{\circ}$ grid. The misfit $(m)$ is expressed as

$$
m=\frac{E_{0}-E_{\mathrm{c}}}{E_{0}-H_{0}} \times 100 \%,
$$

where $E_{0}$ is the mean elevation above sea level of each grid from the ETOP5 model, and $E_{\mathrm{c}}$ is the calculated elevation above sea level for each grid, and $H_{0}$ is depth below sea level of an unloaded asthenospheric mantle $(-2400 \mathrm{~m})$.

The geotherm calculation procedure adopts a fivelayer model, consisting of a sedimentary layer (where present), an upper crust, an upper lower crust, and the lowermost crust, as well as, the lithospheric mantle layer. The heat production is assumed as stepwise distributions with depth (Wang, 2005a, b; Wang and Du, 2004 a, b; Wang and Deng, 2001; Xia et al., 2006; Wang and Sun, 2010). All thermophysical parameters adopted for the geotherm calculation are summarized in Table 1.

Table 1 Parameters used in the local isostasy constrained geotherm modelling

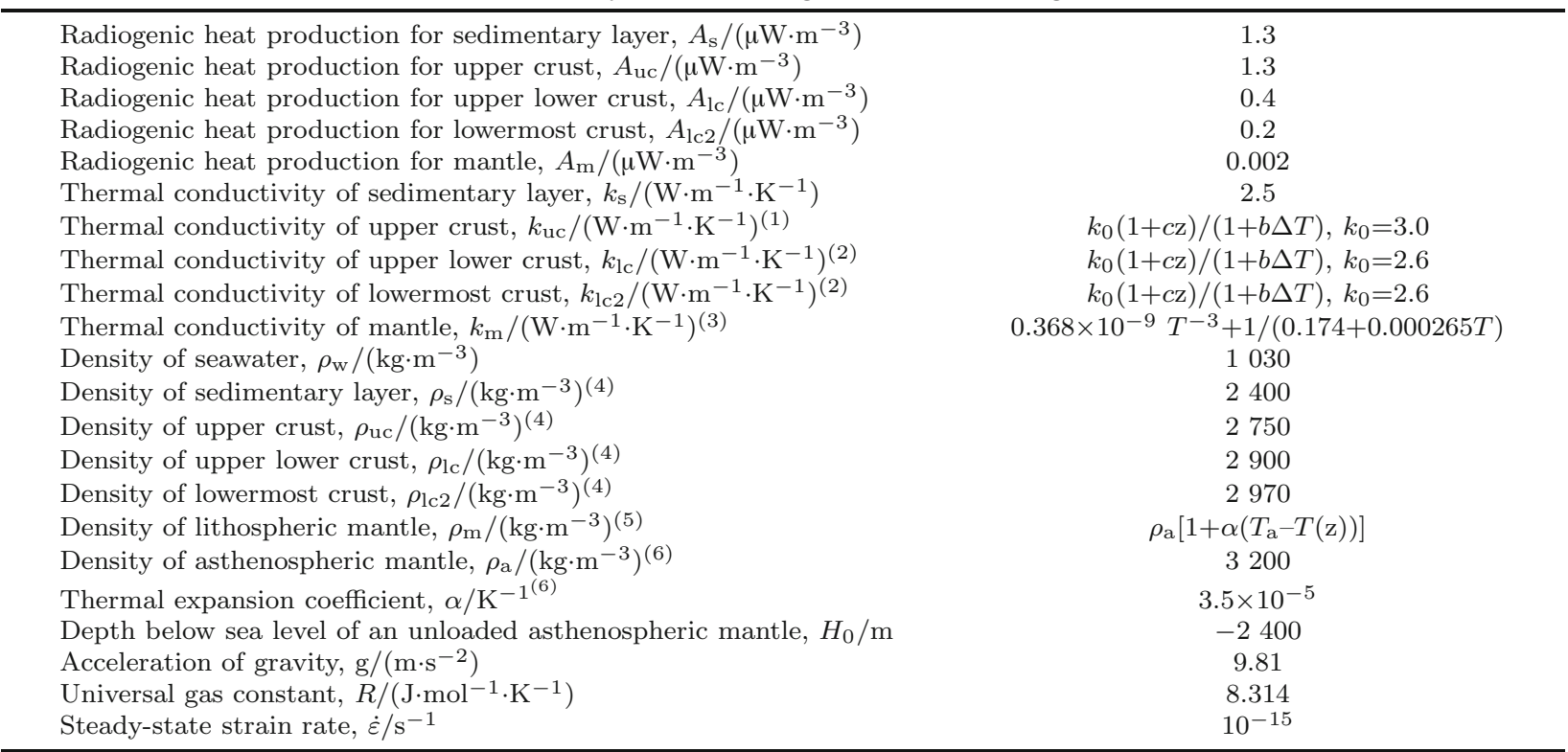

Note: (1) $b=1.5 \times 10^{-3} \mathrm{~K}^{-1}, c=1.5 \times 10^{-3} \mathrm{~km}^{-1}$ (Chapman and Furlong, 1992). ${ }^{(2)} b=1.0 \times 10^{-4} \mathrm{~K}^{-1}, c=1.5 \times 10^{-3} \mathrm{~km}^{-1}$ (Chapman and Furlong, 1992). (3) The unit of $T$ is degree Kelvin (Doin and Fleitout, 1996). (4) According to the experimentally determined $v_{\mathrm{P}}$-density relationship (Christensen and Mooney, 1995). (5) $T_{\mathrm{a}}$ represents the temperature at the lithosphere-asthenosphere boundary, $1350{ }^{\circ} \mathrm{C}$. (6) The values follow Lachenbruch and Morgan (1990). 
The thickness of crust and its sub-layers are obtained from a $1^{\circ} \times 1^{\circ}$ grid crustal $v_{\mathrm{P}}$ model of the Tibetan plateau and its adjacent region (Zhu et al., 2002, 2004; Li et al., 2004; Gao et al., 2005), which covers a rectangular region from $20^{\circ} \mathrm{N}-42^{\circ} \mathrm{N}$ and $73^{\circ} \mathrm{E}-108^{\circ} \mathrm{E}$. For each grid, the uppermost layer with $v_{\mathrm{P}}$ less than 5.4 $\mathrm{km} \cdot \mathrm{s}^{-1}$ are taken as sedimentary layers; and the layer with $v_{\mathrm{P}}$ of 5.4 to $6.4 \mathrm{~km} \cdot \mathrm{s}^{-1}$ is defined as upper crust. In the lower part of crust, the layer with $v_{\mathrm{P}}$ in range from 6.4 to $6.8 \mathrm{~km} \cdot \mathrm{s}^{-1}$ is adopted as the upper lower crust; and the remaining portion with $v_{\mathrm{P}}$ higher than $6.8 \mathrm{~km} \cdot \mathrm{s}^{-1}$ is taken as the lowermost crust. The densities of sedimentary layer, upper crust, upper lower crust, lowermost crust, and mantle are listed in Table 1.

\subsection{Sensitivity analysis}

For the local isostasy-based procedure used in this study, the main uncertainty for modelling result comes from the estimation of the mean crustal density, which is much less than that of the mantle and is determined by the composition and thickness of sub-layers of the crust. Because the $v_{\mathrm{P}}$-density relationship established by experiments is robust (Christensen and Mooney, 1995; Rudnick and Fountain, 1995), the estimate for layer thickness is more critical for our sensitivity analysis. We select five grids representing various tectonic settings as reference models for sensitivity analysis. In calculation, the thickness increases/decreases $1 \mathrm{~km}$ for each sub-layers of crystalline crust (excluding sedimentary layer), with a total variation of $3 \mathrm{~km}$ for the whole crust, to determine the sensitivity of our procedure. The results are presented in Table 2.

The sensitivity analysis shows that the Moho temperature is relative insensitive to the $3 \mathrm{~km}$ variation of the crustal thickness, either are the temperatures at $40 \mathrm{~km}$ and $70 \mathrm{~km}$ depths. The maximum variation of temperature at $40 \mathrm{~km}$ depth is less than $25{ }^{\circ} \mathrm{C}$. Meanwhile the maximum variation of temperature at $70 \mathrm{~km}$ depth is less than $50{ }^{\circ} \mathrm{C}$, and is consistent with the accuracy of the downward continuation calculation for geothermal modelling (Jokinen and Kukkonen, 1999; Artemieva and Mooney, 2001). However, the lithosphere thickness is relatively sensitive to the crustal variation, because of the significant density contrast between crust and mantle. In most cases, a $3 \mathrm{~km}$ variation of crustal thickness causes a $9 \%-16 \%$ depth change of the LAB.

Table 2 Sensitivity analysis for local isostasy constrained geotherm modelling

\begin{tabular}{|c|c|c|c|c|c|c|c|c|c|c|c|}
\hline \multirow[t]{2}{*}{ Location } & \multirow{2}{*}{$\begin{array}{l}\text { Lat. } \\
/{ }^{\circ} \mathrm{N}\end{array}$} & \multirow{2}{*}{$\begin{array}{l}\text { Long. } \\
/{ }^{\circ} \mathrm{E}\end{array}$} & \multirow{2}{*}{$\begin{array}{l}\text { Moho } \\
/ \mathrm{km}\end{array}$} & \multicolumn{2}{|c|}{$\Delta T_{\mathrm{Moho}}^{\mathrm{a}} /{ }^{\circ} \mathrm{C}$} & \multicolumn{2}{|c|}{$\Delta T_{40 \mathrm{~km}}^{\mathrm{b}} /{ }^{\circ} \mathrm{C}$} & \multicolumn{2}{|c|}{$\Delta T_{70 \mathrm{~km}}^{\mathrm{c}} /{ }^{\circ} \mathrm{C}$} & \multicolumn{2}{|c|}{$\Delta L^{\mathrm{d}}$} \\
\hline & & & & $+3^{\mathrm{e}} \mathrm{km}$ & $-3^{\mathrm{f}} \mathrm{km}$ & $+3^{\mathrm{e}} \mathrm{km}$ & $-3^{\mathrm{f}} \mathrm{km}$ & $+3^{\mathrm{e}} \mathrm{km}$ & $-3^{\mathrm{f}} \mathrm{km}$ & $+3^{\mathrm{e}} \mathrm{km}$ & $-3^{\mathrm{f}} \mathrm{km}$ \\
\hline Qilianshan & 38.5 & 98.5 & 64 & +5 & +28 & +5 & +23 & -9 & +49 & $+15 \%$ & $-19 \%$ \\
\hline Qaidam & 37.5 & 94.5 & 54 & +21 & -10 & +13 & -2 & +2 & +16 & $+10 \%$ & $-11 \%$ \\
\hline N. Tibet & 33.5 & 85.5 & 71 & -37 & +31 & -22 & +22 & -48 & +48 & $+23 \%$ & $-14 \%$ \\
\hline E. Tibet & 33.5 & 98.5 & 71 & +20 & +17 & +19 & +9 & +12 & +29 & $+9 \%$ & $-16 \%$ \\
\hline S. Tibet & 29.5 & 90.5 & 72 & -19 & +15 & -15 & +8 & -27 & +27 & $+25 \%$ & $-15 \%$ \\
\hline
\end{tabular}

Note: ${ }^{a}$ Variation of temperature at Moho. ${ }^{\mathrm{b}}$ Variation of temperature at $40 \mathrm{~km}$ depth. ${ }^{\mathrm{c}}$ Variation of temperature at $70 \mathrm{~km}$ depth.

d Relative variation of lithosphere thickness. ${ }^{\text {e }}$ Crustal thickness $3 \mathrm{~km}$ more than reference value in the grid. ${ }^{\mathrm{f}}$ Crustal thickness

$3 \mathrm{~km}$ less than reference value in the grid.

It is suggested that the uncertainty of geothermal modelling due to the crustal structure variation in the Tibetan plateau is not significant. Deep seismic sounding profiles, the basis of the crust model used in this study, had covered the major tectonic domains of the Tibetan plateau (Xiong and Liu, 1997; Zhao et al., 2001; Galvé et al., 2002; Wang et al., 2003; Li et al., 2004; Zhang et al., 2011 and references herein). Accordingly, the accuracy of the crustal $v_{\mathrm{P}}$ model of the western Chinese mainland is warranted, with error of crustal thickness in each $1^{\circ} \times 1^{\circ}$ grid less than $2 \mathrm{~km}$. Therefore, the uncertainty of geothermal modelling for the Tibetan plateau presented here is acceptable for regional scale studies.

\section{Calculation of lithosphere rheol- ogy}

Laboratory rock mechanics studies demonstrate a dependence of rock-strength on temperature and pressure (e.g., Goetze and Evans, 1979). Within the mechanically strong part of the lithosphere, the strength of the upper part is defined by criteria for brittle failure (Byerlee's Law). Creep processes become dominant at temperatures exceeding roughly half the melting temperature of rock (Carter and Tsenn, 1987). Therefore, the strength in the lower part of the lithosphere and the lower part of crust is governed by the temperature 
distribution. Extrapolation of flow laws and laboratory failure criteria (i.e., Byerlee, 1978; Brace and Kohlstedt, 1980) and adopting estimates for tectonic strain-rates and thermal gradients at different depths provide a firstorder description of the strength distribution within the lithosphere. For each depth interval, strengths for both brittle and ductile deformation were calculated, with the lesser of these representing the limiting strength of the lithosphere $\left(\sigma_{\mathrm{v}}\right)$ at that particular depth level (e.g., Ranalli, 1995).

The Byerlee's Law can be expressed as (Sibson, 1974)

$$
\sigma_{\text {brittle }}=\sigma_{1}-\sigma_{3}=\alpha \rho g z(1-\lambda),
$$

where $\alpha$ is a parameter depending on the type of faulting, $\rho$ the average density, $\mathrm{g}$ the gravity acceleration, $z$ is the depth and $\lambda$ is the pore fluid factor. In this study, we take $\alpha=3.0$ (thrust faulting) and a typical ("hydrostatic") $\lambda=0.37$.

Power-creep law is expressed as (Ranalli, 1995)

$$
\sigma_{\text {creep }}=\sigma_{1}-\sigma_{3}=\left(\frac{\dot{\varepsilon}}{A}\right)^{\frac{1}{n}} \exp \left(\frac{Q}{n R T}\right),
$$

where $\dot{\varepsilon}$ is the steady-state strain rate, $T$ the temperature in degree Kelvin, $R$ the universal gas constant, $A$ and $n$ are material creep parameters, and $Q$ the activation energy.

A scalar measure for the total strength of a multilayer lithosphere with a depth-dependent rheology can be obtained by vertically integrating the yield envelope:

$$
S_{\mathrm{L}}=\int_{0}^{h} \sigma_{\mathrm{v}} \mathrm{d} z,
$$

where $S_{\mathrm{L}}$ is the integrated lithospheric strength.

In calculation, a four-layer model, consisting of an upper crust (wet quartzite), the upper lower crust (felsic granulite), a lowermost crust (mafic granulite), and the upper mantle (wet peridotite) is adopted; meanwhile, a steady-state strain rate $\dot{\varepsilon}$ of $10^{-15} \mathrm{~s}^{-1}$ is used. Parameters used for rheological modelling are presented in Tables 1 and 3.

Following Afonso and Ranalli (2004), we calculated relative crust strength for the Tibetan plateau, as the percentage of the crust strength to the integrated strength of whole lithosphere, because the "crème brûlée" here is regarded as all models with a weak mantle but "jelly sandwich" as all models with a strong mantle, not just those with a weak lower crust (Burov and Watts, 2006).

Table 3 Creep parameters for lithospheric rocks

\begin{tabular}{lcccc}
\hline Lithology & $\begin{array}{c}\text { Powerlaw } \\
\text { exponent } n\end{array}$ & $\begin{array}{c}\text { Powerlaw activation } \\
\text { energy } Q /\left(\mathrm{kJ} \cdot \mathrm{mol}^{-1}\right)\end{array}$ & $\begin{array}{c}\text { Pre-exponential constant } \\
(\text { powerlaw }) A /\left(\mathrm{MPa}^{-n} \cdot \mathrm{s}^{-1}\right)\end{array}$ & Kirby and Kronenberg $(1987)$ \\
\hline Wet quartzite & 2.3 & 154 & $2.0 \times 10^{-4}$ & Wilks and Carter (1990) \\
Felsic granulite & 3.1 & 243 & $8.0 \times 10^{-3}$ & Wilks and Carter (1990) \\
Mafic granulite & 4.2 & 445 & $2.4 \times 10^{4}$ & Chopra and Paterson (1984) \\
Wet peridotite & 4.0 & 471 & $2.0 \times 10^{3}$ & Chopra and Paterson (1981) \\
\hline
\end{tabular}

\section{Results and discussion}

The estimated values of surface heat flow are shown in Figure 1. There exists good agreement between the inverted and the observed heat flow values in the Tibetan plateau and its adjacent regions. The inverted heat flow values for the main portion of the Tibetan plateau are in the range of $65-72 \mathrm{~mW} \cdot \mathrm{m}^{-2}$. Hu et al. (2000) argued that the seven unpublished heat flow values from oil company drillings in western Tibet are quite similar to those in eastern Tibet. According to these authors, the measured values are in the range of $61-77 \mathrm{~mW} \cdot \mathrm{m}^{-2}$ for eastern Tibet, when some extreme values from southern Tibet are excluded. The inversion also displays good agreements for the Qilianshan belt $\left(60-65 \mathrm{~mW} \cdot \mathrm{m}^{-2}\right)$ and the Qaidam basin $(60$
$65 \mathrm{~mW} \cdot \mathrm{m}^{-2}$ ) (Wang, 1996; Wang et al., 1996; Wang, 2001). Hence, we suggest our inverted heat flow values may approximate the conductive heat flux from the deep Tibetan plateau.

The lithosphere temperatures for the Tibetan plateau and its surrounding regions are displayed in map view for the depths of $40 \mathrm{~km}, 70 \mathrm{~km}$, and the depth of the Moho (Figures 2-4). At the same depth, the highest temperatures are present within the Tibetan plateau, and the temperatures under the Tarim and the Sichuan basin are much lower. The temperature difference between the tectonically active Tibetan plateau and its surrounding stable regions is greater than $200{ }^{\circ} \mathrm{C}$. For example, the temperatures at $40 \mathrm{~km}$ depth are higher than $800{ }^{\circ} \mathrm{C}$ under the major portion of the Tibetan plateau, but lower than $600{ }^{\circ} \mathrm{C}$ under the 


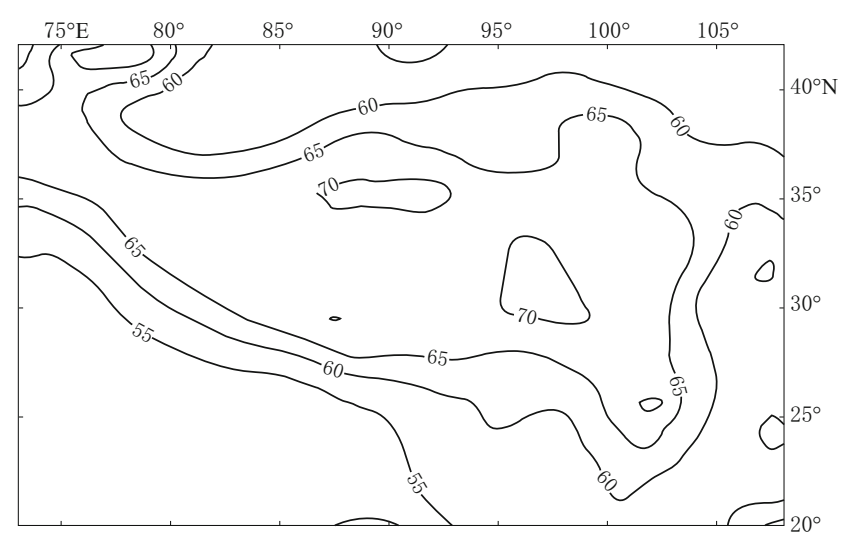

Figure 1 Inverted surface heat flow values for the Tibetan plateau and its adjacent areas $\left(1^{\circ} \times 1^{\circ}\right.$ Kriging interpolation).

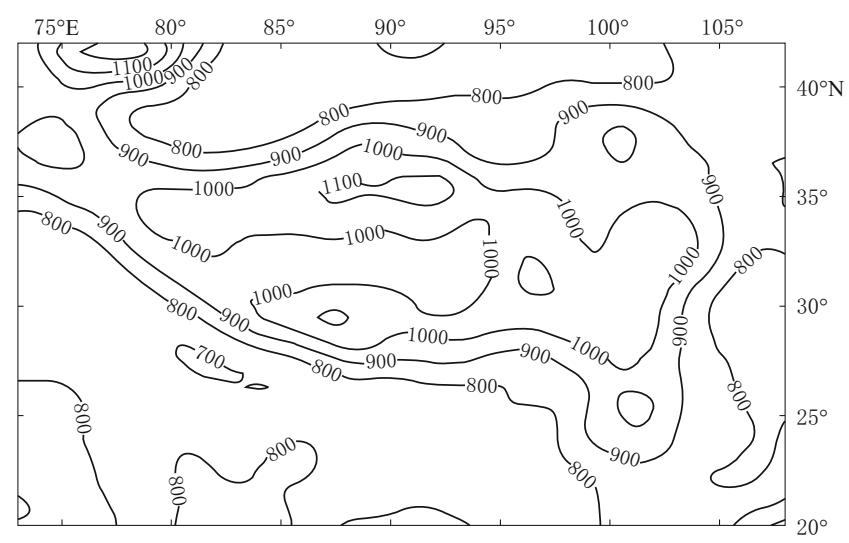

Figure 3 Estimated temperatures at $70 \mathrm{~km}$ depth $\left(1^{\circ} \times 1^{\circ}\right.$ Kriging interpolation) .

Tarim basin (Figure 2). At the depth of the Moho, the typical temperatures are estimated to be $550-650{ }^{\circ} \mathrm{C}$ in the Tarim basin (where the crust is 45 to $50 \mathrm{~km}$ thick); and more than $700{ }^{\circ} \mathrm{C}$ in the thick-crust regions (where the Moho is $>50 \mathrm{~km}$ ); such as the Qaidam basin and the Qilianshan fold belt, as well as the interior of Tibetan plateau. The highest value of Moho temperature within the Tibetan plateau reaches $1200^{\circ} \mathrm{C}$ (Figure 4). There exists good agreement between the Moho temperatures and the $\mathrm{P}$-wave velocities of the uppermost mantle $\left(P_{n}\right)$. The $P_{\mathrm{n}}$ tomography (Hearn et al., 2004; Liang et al., 2004; Pei et al., 2007) shows that the low values occur beneath the northern Tibet and the eastern margin of the plateau, but the high values occur beneath the Tarim and Sichuan basins.

Many geophysical evidences such as the crustal high conductivity zones from natural-source magnetotelluric (MT), the plateau-wide low crustal velocity

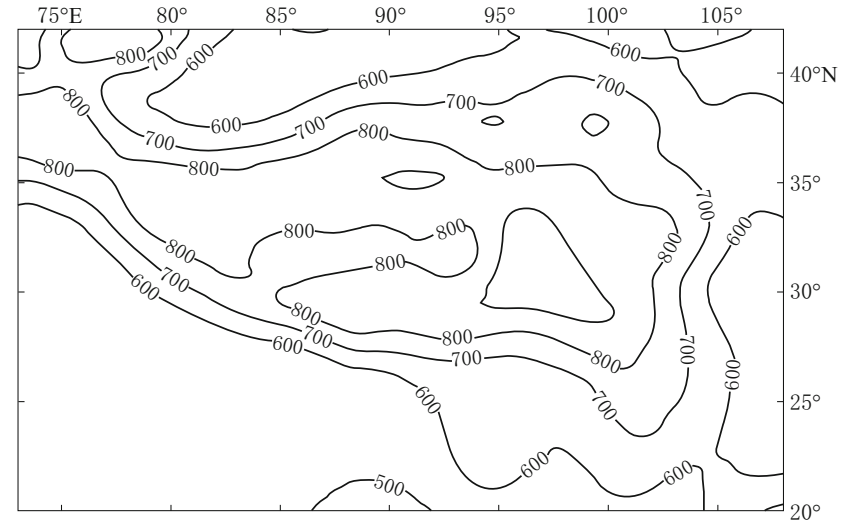

Figure 2 Estimated temperatures at $40 \mathrm{~km}$ depth $\left(1^{\circ} \times 1^{\circ}\right.$ Kriging interpolation $)$.

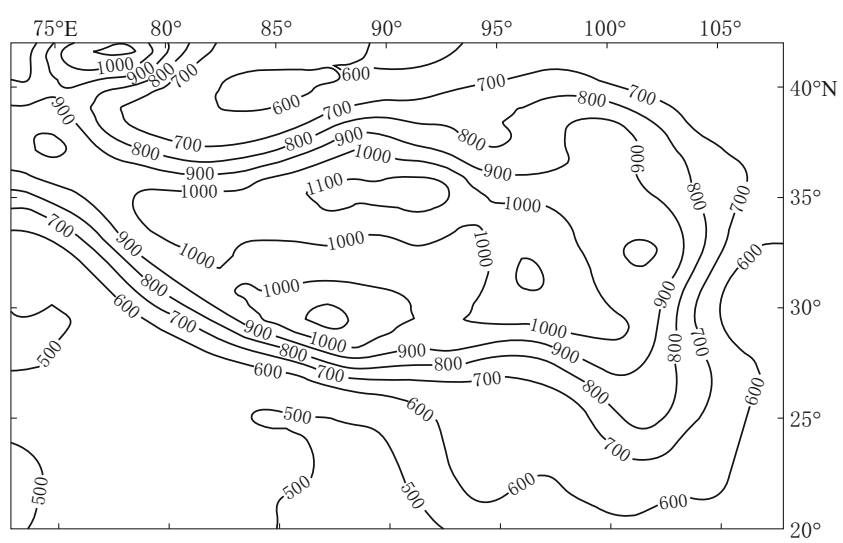

Figure 4 Estimated temperatures at the depth of the Moho $\left(1^{\circ} \times 1^{\circ}\right.$ Kriging interpolation $)$.

from seismic studies, as well as the shallow depth (ca. 15 $\mathrm{km}$ ) of Curie isotherm across the entire plateau, suggest the existence of a hot crust in the Tibetan plateau (cf. Klemperer, 2006). Lebedev and Agius (2009) also identified widespread mid-crust low velocity layer in the Tibetan plateau from surface wave inversion. Meanwhile, the Miocene potassic volcanic rocks in southern Tibet (Ding et al., 2003), as well as the Late Miocene to recent potassic volcanic rocks in the northern Tibet represent the high temperature $\left(c a .1100^{\circ} \mathrm{C}\right)$ melting of the subcontinental mantle (Turner et al., 1996). Accordingly, our thermal study confirms that the entire lithosphere of the Tibetan plateau is hot as suggested by a significant number of geophysical and geological observations (Klemperer, 2006; McKenzie and Priestley, 2008).

The thickness of the thermal lithosphere, here defined as a conductive layer above the $1350{ }^{\circ} \mathrm{C}$ isotherm, is more than $120 \mathrm{~km}$ in the Tibetan plateau (Figure 5). 


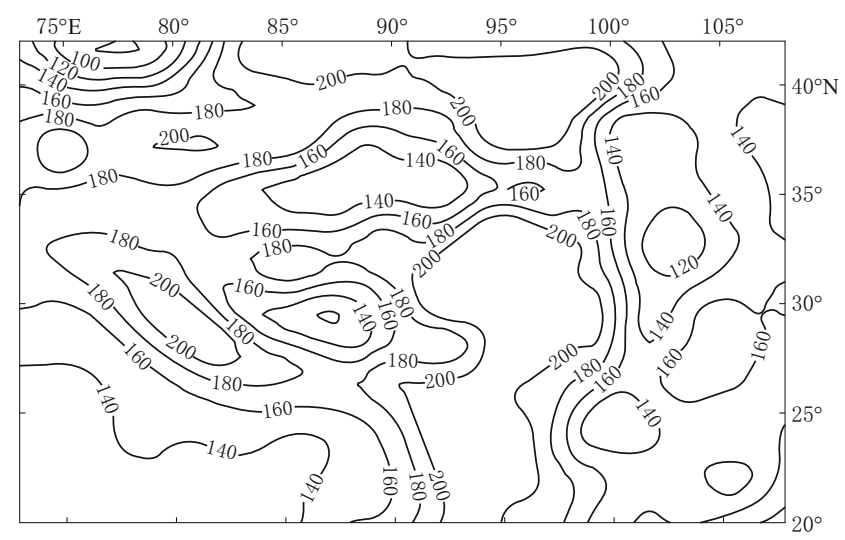

Figure 5 Lithospheric thermal thickness beneath the Tibetan plateau and its adjacent areas $\left(1^{\circ} \times 1^{\circ}\right.$ Kriging interpolation), assumed to be the depth of the $1350{ }^{\circ} \mathrm{C}$ isotherm.

The lithospheric bulge in the eastern Tibet has thickness of $200-240 \mathrm{~km}$. The lithosphere beneath the Qilianshan fold belt is $200 \mathrm{~km}$ thick or more. The thicker lithosphere (160-180 km) also occurs beneath the Tarim and the Sichuan basins. However, the thinner lithosphere $(<140 \mathrm{~km})$ occurs beneath northern Tibet and the eastern margin of the Tibetan plateau (east of $100^{\circ} \mathrm{E}$ median).

The lithospheric thermal thickness of the Tibetan plateau attained by this study is consistent with that from seismic studies. The upper mantle structure implied by $P_{n}$ travel-time tomography (McNamara et al., 1997) and by S-wave velocity anomalies determined from the inversion of fundamental mode Love and Rayleigh waves (Villaseñor et al., 2001) suggests that extreme thinning of the lithospheric mantle occurs beneath northern Tibet. Surface wave inversion by Agius and Lebedev (2009) confirms that a thicker (160$180 \mathrm{~km}$ ) lithosphere exists beneath southern Tibet, but thinner lithospheric mantle under the northern Tibet. From the vertical distribution of shear wave velocity, McKenzie and Priestley (2008) argued that the lithosphere beneath the main portion of the Tibetan plateau is thicker than $180 \mathrm{~km}$. Meanwhile, recent seismic tomography studies suggest that there exists a much thinner lithosphere $(<140 \mathrm{~km})$ beneath the eastern margin of the Tibetan plateau (Feng et al., 2011; Hu et al., 2011). The agreement between thermal modelling and seismic studies means that the geotherms constructed by isostatic equilibrium constraint are reliable.

The thick but warm lithospheres under the Tibetan plateau, and the Qilianshan fold belt correspond to the shortening caused by the convergence of the Indian and the Eurasian plates (Revenaugh and Sipkin, 1994). Houseman and Molnar (2001) pointed out that the thickened lithospheric mantle can cause a disturbance to the rheologically stratified system, which induces Rayleigh-Taylor instability with the denser layer descending as a viscous drop and finally results in the convective thinning of the lithospheric mantle in convergent environments. According to seismic evidence, Houseman and Molnar (2001) suggested that the lithospheric mantle beneath the Tibetan plateau had undergone some form of instability that has led to asthenospheric replacement of some part of the lithospheric mantle. Meanwhile, the basaltic volcanism erupted since ca. $10 \mathrm{Ma}$, especially in the northern Tibet, also implies a thinner lithosphere in the northern Tibet (Arnaud et al., 1992; Turner et al., 1996). Therefore, the results of our geothermal modelling confirm the argument that the current structure of the lithosphere beneath the Tibetan plateau is a snapshot of the early stages of lithosphere instability (Revenaugh and Sipkin, 1994).

The lateral distribution of the integrated lithospheric strength in the Tibetan plateau and its surrounding area is presented in Figure 6, and the relative strength ratios are shown in Figure 7. It is shown that the lithospheric strength is lower than $2 \times 10^{12} \mathrm{~Pa} \cdot \mathrm{m}$ within the Tibetan plateau, due to its over-thickened crust and elevated geotherm. The percentage of the crust strength to the integrated strength of the entire lithosphere across the majority of Tibetan plateau is larger than 90\% (Figure 7), corresponding to a stronger crust, but a weak upper mantle. This means that the present-day rheology of the Tibetan plateau belongs to the typical "crème-brûlée" layering. Previous studies point to the weak $\left(<1 \times 10^{13} \mathrm{~Pa} \cdot \mathrm{m}\right)$ strength of the "crème-brûlée" layering as being earthquake-prone (Wang, 2001; Wang and Cheng, 2012). Accordingly, the high intensity of seismic activity in the Tibetan plateau is determined by rheological characteristics of the lithosphere. Meanwhile, the existence of weak lower crust and upper mantle beneath the Tibetan plateau favors the "channel flow" model of the large-scale deformation (Klemperer, 2006; Beaumont et al., 2006). 


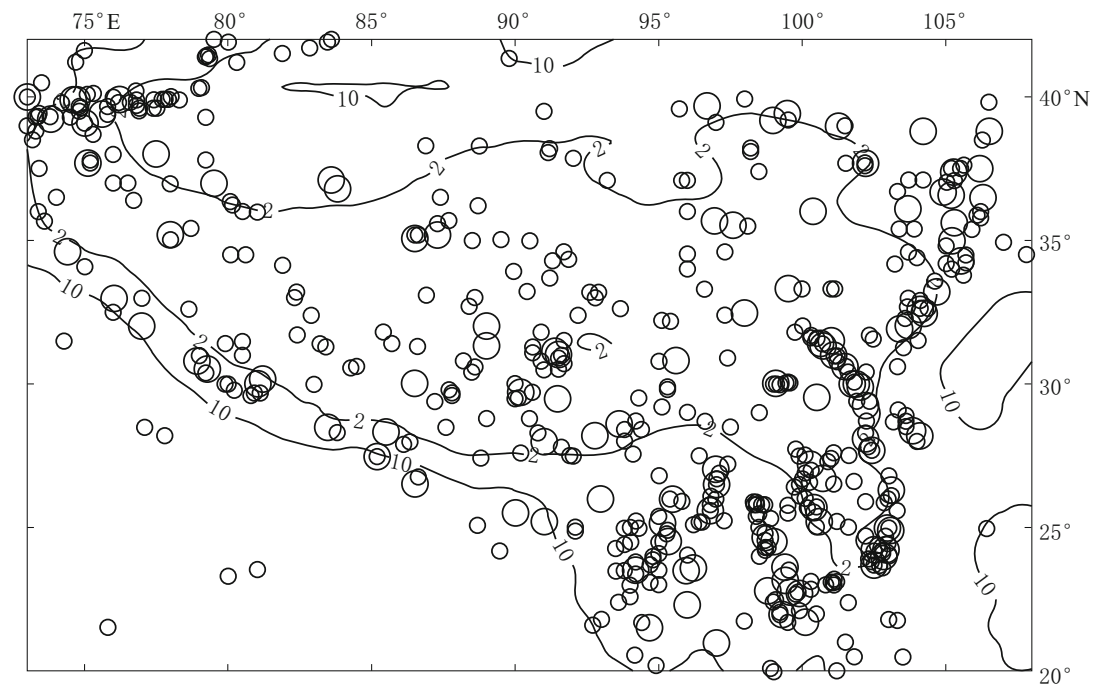

Figure 6 Integrated lithospheric strength (in the unit of $10^{12} \mathrm{~Pa} \cdot \mathrm{m}$ ) of the Tibetan plateau and adjacent areas presented with $1^{\circ} \times 1^{\circ}$ Kriging interpolation. Large circle represents the epicenter of $M_{\mathrm{S}} \geq 7.0$ earthquake, and small circle represents the epicenter of $6.0 \leq M_{\mathrm{S}}<7.0$ earthquake (earthquake catalogue is from Song et al., 2011).

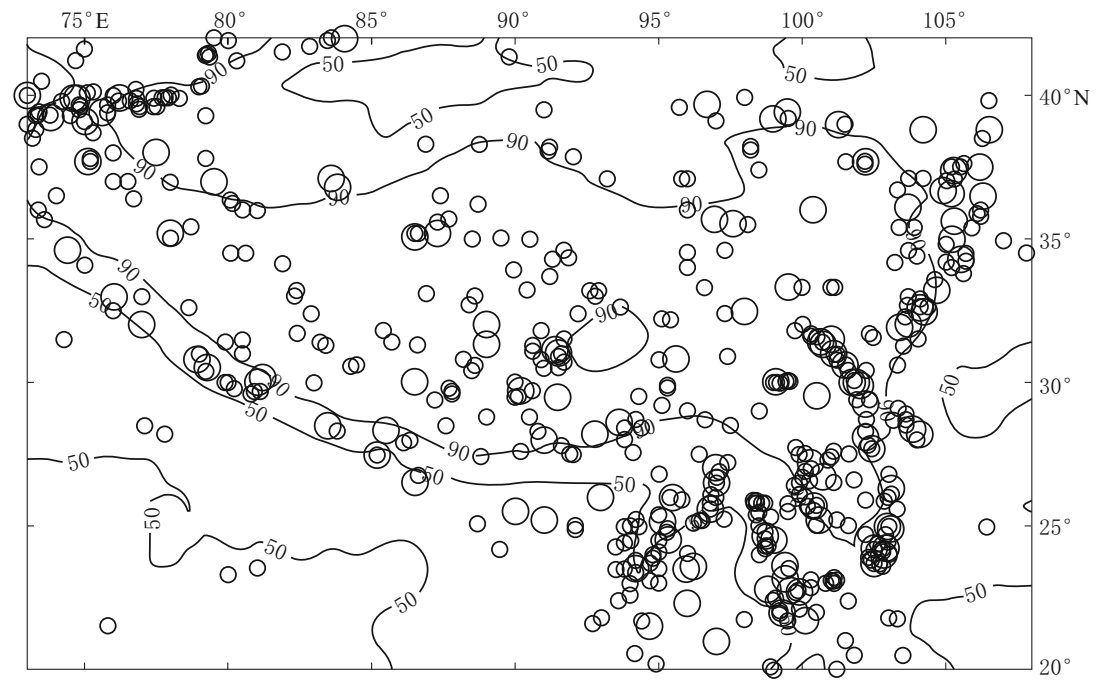

Figure 7 Distribution of the percentage of crust strength relative to lithospheric strength in the Tibetan plateau and adjacent areas presented with $1^{\circ} \times 1^{\circ}$ Kriging interpolation. Large circle represents the epicenter of $M_{\mathrm{S}} \geq 7.0$ earthquake, and small circle represents the epicenter of $6.0 \leq M_{\mathrm{S}}<7.0$ earthquake (earthquake catalogue is from Song et al., 2011).

\section{Conclusions}

The geothermal modelling constrained by local isostatic equilibrium offers reliable estimates for the temperature variations within the lithosphere beneath the Tibetan plateau. In general, the Tibetan plateau is characterized by a warm and thick lithosphere. The temperatures at $40 \mathrm{~km}$ depth are higher than $800{ }^{\circ} \mathrm{C}$ under the major portion of the Tibetan plateau. The typical temperatures at Moho depth are more than $700{ }^{\circ} \mathrm{C}$ in the interior of Tibetan plateau, and the highest value reaches $1200{ }^{\circ} \mathrm{C}$. The thickness of the thermal lithosphere is more than $200 \mathrm{~km}$ beneath eastern Tibet and the Qilianshan fold belt. Meanwhile, the lithosphere is less than $140 \mathrm{~km}$ beneath northern Tibet and the eastern margin of the Tibetan plateau. The thick and hot lithosphere under the Tibetan plateau results from the uniform thickening of the crust and lithospheric mantle. 
However, the thin thermal lithosphere under the northern Tibet indicates the onset of convective thinning. The conclusions of geothermal modeling, presented in this study, are consistent with the results from seismic tomography. The lithospheric rheology of the Tibetan plateau is approximated by the "crème brûlée" layering model, characterized by a strong crust with a weak upper mantle.

Acknowledgements This study is financially supported by the Fundamental Research Funds for the Central Universities (Grant Nos. 2652013021 and 2010ZD15).

\section{References}

Afonso J C and Ranalli G (2004). Crustal and mantle strengths in continental lithosphere: Is the jelly sandwich model obsolete? Tectonophysics 394: 221-232.

Agius M and Lebedev S (2009). Surface-wave phase-velocity analysis across the Tibetan plateau using broadband inter-station dispersion measurements. Abstracts of 5th International Symposium on the Tibetan plateau and 24th Himalaya-Karakorum-Tibet Workshop, 11-14 August 2009, Beijing, China, 258.

Arnaud N O, Vidal Ph, Tapponnier P, Matte $\mathrm{Ph}$ and Deng W M (1992). The high $\mathrm{K}_{2} \mathrm{O}$ volcanism of northwestern Tibet: Geochemistry and tectonic implications. Earth Planet Sci Lett 111: 351-367.

Artemieva I M and Mooney W D (2001). Thermal thickness and evolution of Precambrian lithosphere: A global study. J Geophys Res 106: 16 387-16 414.

Beaumont C, Nguyen M H, Jamieson R A and Ellis S (2006). Crustal flow modes in large hot orogen. In: Law R D, Searle M P and Godin L eds. Channel Flow, Ductile Extrusion and Exhumation in Continental Collision Zones. Special Publications. Geological Society, London, 268: 91-145.

Brace W F and Kohlstedt D L (1980). Limits on lithospheric stress imposed by laboratory experiments. J Geophys Res 85: 6 248-6 252 .

Burov E B and Watts A B (2006). The long-term strength of continental lithosphere: "jelly sandwich" or "crème brûlée"? GSA Today 16: 4-10.

Byerlee J (1978). Friction of rocks. Pure Appl Geophys 116: 615-626.

Carter N L and Tsenn M C (1987). Flow properties of continental lithosphere. Tectonophysics 136: 27-63.

Chapman D S and Furlong K P (1992). Thermal state of the continental lower crust. In: Fountain D M, Arculus $\mathrm{R}$ and Kay R W eds. Continental Lower Crust. Elsevier, Amsterdam, 179-199.

Chopra P N and Paterson M S (1981). The experimental deformation of dunite. Tectonophysics 78: 453-473.

Chopra P N and Paterson M S (1984). The role of water in the deformation of dunite. J Geophys Res 89: $7861-7876$.

Christensen N I and Mooney W D (1995). Seismic velocity structure and composition of the continental crust: A global view. J Geophys Res 100: 9 761-9 788.

Ding L, Kapp P, Zhong D and Deng W (2003). Cenozoic volcanism in Tibet: Evidence for a transition from oceanic to continental subduction. J Petrol 44: 1 833-1 865.

Doin M P and Fleitout L (1996). Thermal evolution of the oceanic lithosphere: An alternative view. Earth Planet Sci Lett 142: 121-136.

Feng M, An M, Zhao W, Xue G, Mechie J and Zhao J (2011). Lithosphere structures of northeast Tibetan plateau and their geodynamic implications. Journal of Geodynamics 52: 432-442.

Galvé A, Hirn A, Jiang M, Gallart J, Voogd B, Lépine J C, Diaz J, Wang Y X and Qian H (2002). Modes of raising northeastern Tibet probed by explosion seismology. Earth Planet Sci Lett 203: 35-43.

Gao X, Wang W M and Yao Z X (2005). Crustal structure of China mainland and its adjacent regions. Chinese $J$ Geophys 48: 591-601 (in Chinese with English abstract).

Goetze C and Evans B (1979). Stress and temperature in the bending lithosphere as constrained by experimental rock mechanics. Geophys J R astr Soc 59: 463-478.

Hearn T M, Wang S, Ni J F, Xu Z, Yu Y and Zhang $\mathrm{X}$ (2004). Uppermost mantle velocities beneath China and surrounding regions. J Geophys Res 109: B11301, doi:10.1029/2003JB002874.

Houseman G and Molnar P (2001). Mechanisms of lithospheric rejuvenation associated with continental orogeny. In: Miller J A, Holdsworth R E, Buick I S and Hand $\mathrm{M}$ eds. Continental Reactivation and Reworking. Special Publications. Geological Society, London, 184: 13-38.

$\mathrm{Hu}$ J, Xu X, Yang H, Wen L and Li G (2011). S receiver function analysis of the crustal and lithospheric structures beneath eastern Tibet. Earth Planet Sci Lett 306: 77-85.

$\mathrm{Hu} \mathrm{S}$, He L and Wang J (2000). Heat flow in the continental area of China: A new data set. Earth Planet Sci Lett 179: 407-419.

$\mathrm{Hu}$ S, He L and Wang J (2001). Compilation of heat flow data in the China continental area (3rd edition). Chinese J Geophys 44: 611-626 (in Chinese with English abstract).

Huang S, Wang J Y and Chen M (1996a). The map of temperature at Moho (1:12 000 000). In: Yuan X C ed. Atlas of Geophysics in China. Publication No. 201 of the International Lithosphere Program. Geological Publishing House, Beijing, 106-107.

Huang S, Wang J Y and Chen M (1996b). The map of thickness of the thermal lithosphere (1:12 000 000). In: Yuan 
X C ed. Atlas of Geophysics in China. Publication No. 201 of the International Lithosphere Program. Geological Publishing House, Beijing, 108-109.

Jokinen J and Kukkonen I T (1999). Random modelling of the lithospheric thermal regime: Forward simulations applied in uncertainty analysis. Tectonophysics 306: 277292.

Kirby S H and Kronenberg A K (1987). Rheology of the lithosphere: Selected topics. Rev Geophys 25: 1 2191244.

Klemperer S L (2006). Crustal flow in Tibet: Geophysical evidence for the physical state of Tibetan lithosphere, and inferred patterns of active flow. In: Law R D, Searle M P and Godin L eds. Channel Flow, Ductile Extrusion and Exhumation in Continental Collision Zones. Special Publications. Geological Society, London, 268: 39-70.

Lachenbruch A H and Morgan P (1990). Continental extension, magmatism and elevation: Formal relations and rules of thumb. Tectonophysics 174: 39-62.

Lebedev S and Agius M (2009). Seismic structure of Tibet: New constraints from surface waves. Abstracts of 5th International Symposium on the Tibetan plateau and 24th Himalaya-Karakorum-Tibet Workshop, 11-14 August 2009, Beijing, China, 30.

Li Q S, Peng S P and Gao R (2004). A review on the Moho discontinuity beneath the Tibetan plateau. Geological Review 50: 598-612 (in Chinese with English abstract).

Liang C, Song X and Huang J (2004). Tomographic inversion of Pn travel times in China. J Geophys Res 109: B11304, doi:10.1029/2003JB002789.

McKenzie D and Priestley K (2008). The influence of lithospheric thickness variations on continental evolution. Lithos 102: 1-11.

McNamara D E, Walter W R, Owens T J and Ammon C J (1997). Upper mantle velocity structure beneath the Tibetan plateau from Pn travel-time tomography. J Geophys Res 102: 493-505.

Pei S, Zhao J, Sun Y, Xu Z, Wang S, Liu H, Rowe C A, Toksöz M N and Gao X (2007). Upper mantle seismic velocities and anisotropy in China determined through Pn and Sn tomography. J Geophys Res 112: B05312, doi:10.1029/2006JB004409.

Ranalli G (1995). Rheology of the Earth (2nd Edition). Chapman and Hall, London, 413pp.

Revenaugh J and Sipkin S A (1994). Mantle discontinuity structure beneath China. J Geophys Res 99: 21 91121927.

Rudnick R L and Fountain D M (1995). Nature and composition of the continental crust: a lower crustal perspective. Rev Geophys 33: 267-309.

Sibson R H (1974). Frictional constraints on thrust, wrench and normal faults. Nature 249: 542-544.

Song Z P, Zhang G M and Liu J (2011). Global Earthquake

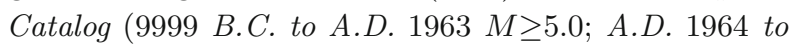

A.D. $2010 M \geq 6.0$ ). Seismological Press, Beijing, 450pp. Turner S P, Arnaud N, Liu J, Rogers N, Hawkesworth C, Harris N, Kelley S P, van Calsteren P and Deng W (1996). Post-collison, shoshonitic volcanism on the Tibetan plateau: Implications for convective thinning of the lithosphere and the source of ocean island basalt. $J$ Petrol 37: 45-71.

Villaseñor A, Ritzwoller M H, Levshin A L, Barmin M P, Spakman W, Trampert J and Engdahl E R (2001). Shear velocity structure of central Eurasia from inversion of surface wave velocities. Phys Earth Planet Inter 123: 169-184.

Wang C Y, Han W B, Wu J P, Lou H and Bai Z M (2003). Crustal structure beneath the Songpan-Garze orogenic belt. Acta Seismologica Sinica 16: 229-241.

Wang J Y ed. (1996). Geothermics in China. Seismological Press, Beijing, 1-299.

Wang J Y and Huang S (1990). Compilation of heat flow data the China continental area (2nd edition). Seismology and Geology 12: 359-366.

Wang J Y, Huang S and Chen M (1996). The map of terrestrial heat flow (1:12 000 000). In: Yuan X C ed. Atlas of Geophysics in China. Publication No. 201 of the International Lithosphere Program. Geological Publishing House, Beijing, 102-103.

Wang Y (2001). Heat flow pattern and lateral variations of lithosphere strength in China mainland: Constraints on active deformation. Phys Earth Planet Inter 126: 121146.

Wang Y (2005a). Comparison of element abundances between the exposed crust of the continent of China and the global average continental upper crust: constraints on the crustal evolution and some speculations. Geological Bulletin of China 24: 906-915 (in Chinese with English abstract).

Wang Y (2005b). Element geochemical characteristics of the supra-crust of eastern Junggar region, Xinjiang and its geological implication. Beijing Geology 17(2): 14-19 (in Chinese with English abstract).

Wang Y and Cheng S H (2012). Lithospheric thermal structure and rheology of the eastern China. Journal of Asian Earth Sciences 47: 51-63.

Wang Y and Deng J (2001). Lateral variation of crustal composition in China as revealed by heat flow study. Earth Science--Journal of China University of Geosciences 26: 597-602 (in Chinese with English abstract).

Wang Y and Du P (2004a). Element geochemical characteristics of the supra-crust of Tianshan Region. Bulletin of Mineralogy, Petrology and Geochemistry 23: 5-9 (in Chinese with English abstract).

Wang Y and Du P (2004b). Element geochemical characteristics of the supra-crust of Altay range in China. Global Geology 23: 144-148 (in Chinese with English abstract). Wang Y and Sun Z M (2010). Crustal composition of China 
continent constrained from heat flow data and helium isotope ratio of underground fluid. Acta Geologica Sinica (English Edition) 84: 178-184.

Wilks K R and Carter N L (1990). Rheology of some continental lower crustal rocks. Tectonophysics 182: 57-77.

Xia X F, Wang Y and Du P (2006). Geological significance of the element geochemical characteristics of the supracrust of Western Junggar region, Xinjiang. Xinjiang Geology 20: 21-25 (in Chinese with English abstract).

Xiong S B and Liu H B (1997). Crustal structure in western Tibet Plateau. Chinese Science Bulletin 42: 665-668 (in Chinese with English abstract).

Zeyen H and Fernandez M (1994). Integrated lithospheric modeling combing thermal, gravity, and local isostasy analysis: Application to the NE Spanish geotransect. $J$ Geophys Res 99: 18 089-18 102.

Zhang Z J, Yang L Q, Teng J W and Badal J (2011). An overview of the earth crust under China. Earth Science Reviews 104: 143-166.

Zhao W, Mechie J, Brown L D, Guo J, Haines S, Hearn T, Klemperer S L, Ma Y S, Meissner R, Nelson K D, Ni J F, Pananont P, Rapine R, Ross A and Saul J (2001). Crustal structure of central Tibet as derived from project INDEPTH wide-angle seismic data. Geophys J Int 145: 486-498.

Zhu J S, Cao J M. and Cai X L (2002). High resolution surface wave tomography in east Asia and west Pacific marginal seas. Chinese J Geophys 45: 679-698 (in Chinese with English abstract).

Zhu J S, Cao J M, Cai X L and Yan Z Q (2004). The structure of lithosphere in Eurasia and West Pacific. Advance in Earth Sciences 19: 387-392 (in Chinese with English abstract). 